\title{
TEORI TENTANG KEDAULTAN ALLAH DALAM MISI
}

\author{
Dr. Jonidius Illu, M.Th. \\ Sekolah Tinggi Teologi Injili Arastamar (SETIA) Jakarta, \\ joillu@sttsetia.ac.id
}

\begin{abstract}
Abstrak
Manusia adalah pribadi yang mulia dan berbeda dengan ciptaan lain oleh karena diciptakan menurut gambar dan rupa Allah dan, diberi hikmat oleh Allah tidak seperti ciptaan lain dan diberi mandat langsung dari Allah, baik mandat ilahi dan mandat budaya. Manusia hadir di bumi dengan tujuan agar segenap hidupnya mempermuliakan Allah dalam berbagai aspek, Allah memberikan tanggungjawab, namun manusia telah gagal dalam tahap ini oleh karena manusia tidak bertanggungjawab ketika diberi perintah, yaitu semua buah pohon boleh kamu makan tetapi pohon pengetahuan tentang yang baik dan jahat jangan kamu memakannya nanti kamu mati (Kej. 3), akibatnya manusia menjadi rusak akibat dosa (Roma 3:23) dan efeknya semua manusia menjadi rusak secara total dan tidak ada wewenang yang mutlak untuk memperbaiki diri seperti keadaan semula ketika manusia diciptakan. Hubungan yang harmonis karena Allah yang beranugrah bagi manusia dalam menggenapkan covenan-Nya bagi manusia. Orang percaya yang sudah menikmati covenan tersebut perlu bersikap respon yang baik dalam hal tersebut.
\end{abstract}

\section{A. PENDAHULUAN}

Beberapa pertanyaan yang kiranya memberika kesadaran bagi kita sebagai orang percaya antara lain: Apakah kita yang sudah menikmati anugrah bersikap diam?, apakah kita yang sudah menikmati kebaikan Allah, tidak meresponi karya Allah yang sedang dinyatakan bagi dunia yang berdosa?, atau apakah misi Allah yang sudah ditugaskan bagi orang percaya di tengah-tengah dunia yang semakin jahat, tidak diberi perhatian oleh orang percaya? Apakah sikap kita sebagai orang percaya sudah memberi pengaruh yang positif bagi dunia atau apakah justru dunia mengejek karena orang percaya tidak bersikap yang baik? Dan apakah kita yakin bahwa Allah berdaulat mengubahkan orang yang berdosa agar kembali kepada Sang Pencipta?

Dari penjelasan di atas, kita menyadari bahwa semua manusia yang ada sampai hari ini telah dipengaruhi dan dikotori oleh dosa secara otomatis sehingga secara rohani kita mengalami krisis kedekatan dengan Tuhan (jauh dengan Allah), tetapi oleh anugrah Allah memungkinkan kita untuk beriman kepada Yesus sebagai Tuhan dan Juruselamat dan memperbaruhi hubungan denganAllah melalui Yesus serta meninggalkan hal-hal duniawi atau perbuatan duniawi karena status kita disebut sebagai anak-anak Allah. Ini ini terjadi karena Allah yang berdaulat sanggup mengubahkan manusia. 


\section{B. PEMBAHASAN}

\section{KERANGKA TEORI TENTANG KEDAULATAN ALLAH DALAM MISI a. Gambaran umum tentang kedaulatan Allah}

Pada bagian ini, penulis menjelaskan arti kedaulatan Allah, dasar Alkitab tentang kedaulatan Allah, makna teologis tentang kedaulatan Allah dan implikasi kedaulatan Allah bagi orang percaya.

\section{1) Arti kedaulatan Allah}

Salah satu sifat Allah adalah kedaulatan Allah. Allah sebagai pribadi yang berdaulat, yang telah menciptakan segala sesuatu dan memegang kekuasaan tertinggi atas segala yang diciptakan-Nya. Ini menunjukkan bahwa manusia berada dalam suatu keyakinan bahwa ada Allah sebagai Pribadi yang menguasai segala isi dunia karena Allah-lah yang menciptakan segala isi dunia.

Kedaulatan Allah diartikan sebagai Pribadi yang berdaulat atas segala sesuatu, baik yang berada di dunia dan yang di Sorga. Hal tersebut ditegaskan oleh Stephen Tong bahwa, "Allah adalah Allah yang mempunyai kedaulatan yang tidak boleh diganggu gugat atau ditawar oleh manusia."

Semua dalam kedaulatan Allah yang dapat dikontrol oleh-Nya. Ini artinya bahwa sifat Allah yang tidak dapat dibatasi oleh apa pun juga dan memiliki kedaulatan yang tak terbatas atas apa saja.

Dari penjelasan di atas, bahwa kedaulatan Allah juga berkaitan dengan kehendak-Nya terhadap segala sesuatu yang berada di bawah kolong langit ini. Dengan kata lain, kedaulatan Allah berperan penting atas apa saja dalam menjalankan kehendak-Nya, baik yang berhubungan dengan dunia sebagai ciptaan-Nya termasuk manusia yang diciptakan menurut gambar dan rupa Allah dan Sorga sebagai tempat kediaman-Nya.

\section{2) Dasar Alkitab tentang kedaulatan Allah}

Pada bagian dasar Alkitab ini, penulis menjelaskan tentang kedaulatan Allah dalam Perjanjian Lama dan Perjanjian Baru

a) Perjanjian Lama

Ada banyak ayat-ayat Alkitab dalam Perjanjian Lama yang menunjukkan bahwa Allah berdaulat, misalnya dalam Kejadian 14:19, berbunyi: “... Allah yang Mahatinggi, Pencipta langit dan bumi," dan beberapa ayat Alkitab yang lain adalah Keluaran 18:11; Ulangan 10:14, 17; 1 Tawarikh 29:11-12; 2 Tawarikh 20:6; Nehemia 9:6; Mazmur 22:28; 47:2, 3, 7, 8; Mazmur 50:10-12; 95:3-5; 115:3; 135:5-6; 145:11-13; Yeremia 27:5.

Ayat-ayat Alkitab tersebut memberikan menegaskan bahwa Allah berdaulat atas segala sesuatu, Ia-lah pemilik langit dan bumi, yang kekuasaan-Nya mengatasi langit dan bumi serta tidak ada sesuatu pun yang menyamakan Dia dengan apa pun. Kedaulatan-Nya dapat mengalahkan kekuatan apa pun juga.

Jadi kedaulatan Allah dalam berkaitan dengan kekuasaan Allah yang dapat mengontrol segala sesuatu, tidak ada sesuatu yang bisa menyamakan diri-Nya dan kedaulatan Allah dapat memerintah segala sesuatu.

b) Perjanjian Baru

Perjanjian Baru juga menegaskan hal kedaulatan Allah, seperti dalam Kisah Para Rasul 17:24-26 berbunyi, 
"Allah yang telah menjadikan bumi dan segala isinya, Ia yang adalah Tuhan atas langit dan bumi, tidak diam dalam kuil-kuil buatan tangan manusia dan juga tidak dilayani oleh tangan manusia, seolah-olah Ia kekurangan apa-apa, karena Dialah yang memberikan hidup dan nafas dan segala sesuatu kepada semua orang. Dari satu orang saja Ia telah menjadikan semua bangsa dan umat manusia untuk mendiami seluruh muka bumi dan Ia telah menentukan musimmusim bagi mereka dan batas-batas kediaman mereka."

Ada beberapa ayat lain dalam Perjanjian Baru yang juga menunjukkan bahwa Ia adalah Allah yang berdaulat atas seluruh ciptaan antara lain: Lukas 1:53; Wahyu 19:6. Kedua ayat ini juga menegaskan bahwa Allah sebagai Pribadi yang berdaulat dari kekal sampai kekal dan tidak sesuatu apa pun dan tidak seorang pun menyamakan dirinya dengan kedaulatan Allah yang ajaib tersebut.

Jadi, baik dalam Perjanjian Lama dan Perjanjian Baru, menegaskan kepada kita

- bahwa Allah-lah sebagai pemilik segala sesuatu

- Allah berdaulat dari kekal sampai kekal dan tidak ada sesuatu pun yang menyamakan diri-Nya dengan Allag

- Kedaulatan Allah dapat mengendalikan apa pun juga termasuk kekuasaan Setan.

\section{3) Makna teologis tentang kedaulatan Allah}

Beberapa bagian yang penulis jelaskan berkaitan dengan makna teologis tentang kedaulatan Allah antara lain:

a) Allah yang menciptakan segala sesuatu

Kejadian 1:1, berbunyi, "Pada mulainya Allah menciptakan langit dan bumi." Semua ciptaan Allah baik dalam menyediakan apa yang dibutuhkan oleh manusia. Ini menunjukkan bahwa Allah adalah Pribadi yang menetapkan apa yang baik bagi manusia.

Dunia ini ada tidak dengan sendirinya tetapi Allah sebagai sumber dari segala yang telah ada dan Allah berdaulat atas semua ciptaan-Nya karena Allah sebagai Pencipta.

b) Allah yang berkuasa atas segala sesuatu

Allah adalah mahakuasa (omnipotence) dan dapat melakukan apa saja menurut kehendak-Nya atau Allah dapat melakukan segala sesuatu yang selaras dengan natur dan pribadi-Nya.

Allah adalah Pribadi yang mahakuasa maka Allah dapat melakukan segala sesuatu dengan mungkin (Mat. 19:26). Allah dapat melakukan segala sesuatu, tidak ada yang terlalu sukar bagi Allah.

Allah melakukan apa yang diinginkan-Nya (Mzm. 115:3) dan menetapkan segala sesuatu sesuai dengan kehendak-Nya (Ef. 1:11).

Allah tidak dapat melakukan sesuatu yang tidak selaras dengan natur-Nya. Allah tidak dapat menyangkal perkataan-Nya (2 Tim. 2:13). Allah tidak dapat berdusta (Ibr. 6:18). Allah tidak berhubungan dengan dosa (Hab. 1:13; Yak. 1:13), karena Allah dapat melakukan segala sesuatu yang diinginkan-Nya sehingga doktrin kemahakuasaan Allah menjadi sumber penghiburan yang besar bagi orang percaya (lihat Kej. 18:14; 1 Pet.1:5). 


\section{PHRONESIS: JURNAL TEOLOGI DAN MISI \\ VOL. 1 NO. 1 EDISI JANUARI-JUNI 2018. ISSN. 262 1-2684}

Karena Allah adalah pencipta segala sesuatu maka Allah berkuasa atas segala sesuatu yang telah diciptakan-Nya. Kemahakuasaan Allah tidak dapat dibatasi oleh apa pun juga. Ini bukan berarti Allah dapat melakukan segala sesuatu dengan seenaknya tetapi sesuai dengan kesempurnaan Allah dan apa yang sesuai dengan kekudusan-Nya.

c) Allah yang mengendalikan dan mengontrol segala sesuatu

Karena Allah adalah Pencipta segala sesuatu dan Allah memiliki kemahakuasaan yang tidak terbatas, maka Allah dapat mengendalikan dan mengontrol segala sesuatu. Artinya segala sesuatu yang terjadi dalam dunia, semuanya bisa dikendalikan dan dikontrol oleh Allah.

Contoh dalam Alkitab, Allah menyeberangkan orang Israel, Allah dengan kemahakuasaan-Nya dapat menjaga orang Israel sehingga mereka menyeberangi laut Teberau dan Allah mengendalikan air laut sehingga air laut seperti tembok. Contoh lain dalam Perjanjian Baru misalnya angin ribut diredakan oleh Yesus.

\section{4) Implikasi kedaulatan Allah bagi orang percaya}

Pada bagian ini, penulis menjelaskan beberapa hal yang berkaitan dengan implikasi kedaulatan Allah bagi orang percaya antara lain:

a) Allah menggenapkan rencana keselamatan bagi orang percaya

Manusi jatuh dalam dosa sebagai akibat dari kebebasan yang salah digunakan. Kebebasan yang Allah berikan adalah berkarya dalam menjalankan kehendak Allah, namun manusia gagal sebagai makhluk yang tidak dapat mempertanggungjawabkan kehendak bebas tersebut.

Allah menciptakan manusia, dengan tujuan memuliakan Allah, namun manusia mengalami kejatuhan dalam dosa yang mengakibatkan terjadi kerusakan secara total dan akibatnya manusia mengalami hukuman kekal, sebagai akibat dari pemberontakannya kepada Allah.

Dari kejatuhan manusia tersebut, maka tidak ada cara lain atau usaha manusia dalam memulihkan hubungan yang sudah rusak dengan Allah.

Kejatuhan manusia dalam dosa, mengakibatkan ada proteevanggelion dalam Kejadian 3:15. Ayat ini menjelaskan bahwa perjanjian keselamatan sebagai cara Allah memulihkan manusia dengan Allah sudah dimulai. Pelaksaan akan janji secara nyata sejak kelahiran Yesus dan penderitaan serta puncaknya adalah kematian Yesus. Yesus sendiri mengatakan bahwa sudah selesai (tetelestai). Istilah sudah selesai menunjukkan bahwa semua dosa sudah ditanggung-Nya di atas kayu salib. Dengan kata lain bahwa tidak ada cara lain atau tidak ada usaha dari pihak manusia untuk memulihkan hubungan yang sudah rusak akibat dosa kecuali dengan kehadiran Yesus di dunia.

Dari penjelasan di atas, penulis melihat dari sisi teologis bahwa Allah dalam kekekalan sudah menciptakan dan merencanakan keselamatan bagi manusia yang berdosa dan digenapkan dalam diri Yesus Kristus.

b) Allah memelihara orang percaya

Allah yang telah menciptakan langit dan bumi termasuk manusia dan tidak hanya manusia diciptakan, tetapi juga manusia dipelihara oleh Allah.

Wesley J. Brill, menjelaskan bahwa, 'pemeliharaan Allah merupakan kuasa Allah yang berlaku atas makhluk-Nya dan ciptaan-Nya, dengan kuasa-Nya itu semua diatur dan dipelihara sampai maksud Allah digenapikan dalam makhluk-Nya.' 


\section{PHRONESIS: JURNAL TEOLOGI DAN MISI \\ VOL. 1 NO. 1 EDISI JANUARI-JUNI 2018. ISSN. 262 1-2684}

Dosa yang begitu berat saja sudah diselesaikan oleh Allah di dalam pribadi Yesus Kristus, apalagi hal-hal yang berkaitan dengan proses kehidupan manusia dengan berbagai hal-hal yang dibutuhkan oleh manusia.

Roma 8:28-29, menjelaskan bahwa, "Allah turut bekerja sama dalam segala sesuatu untuk mendatangkan kebaikan bagi orang yang mengasihi Dia, yaitu bagi mereka yang terpanggil sesuai dengan rencana Allah, sebab semua orang yang dipilih-Nya mereka itu juga yang ditentukan-Nya ....". ayat ini menjelaskan kepada kita bahwa Allah dalam comman grace Allah memberikan apa saja kepada semua orang tanpa terkecuali, tetapi dalam konteks special grace, ini berkenan dengan keselamatan kepada mereka yang percaya kepada Yesus secara pribadi sebagai Tuhan dan Juruselamat.

Allah memberikan keselamatan secara gratis bagi orang percaya (Ef. 2:8-9), maka Allah juga menjanjikan akan pemeliharaan bagi orang yang percaya.

Alkitab memberikan contoh tentang Sadrakh, Mesakh dan Abednego dalam Kitab Daniel 3, bahwa Allah membebaskan mereka dari nyala api. Perjanjian Baru juga mencatat mengenai Paulus di Malta, bahwa ia digigit oleh ular berbisa tetapi Paulus tidak mengalami kematian.

Penulis menjelaskan bahwa pemeliharaan Allah nyata bagi orang percaya, walaupun mengalami situasi yang sangat sulit, tetapi diberikan keteguhan iman dalam menghadapi semuanya dengan kekuatan yang dianugrahkan Allah (2 Kor. 1:89).

c) Allah menjanjikan Sorga yang kekal bagi orang percaya

Keberdosaan manusia mengalami hukuman kekal. Kita bersyukur kepada Allah dalam Kristus karena berkat keselamatan dianugrahkan kepada setiap orang yang percaya.

Pada waktu seseorang percaya kepada Yesus sebagai Tuhan dan Juruselamat secara pribadi, maka saat itu juga ia pasti selamat. Dengan kata lain bahwa keselamatan atau kehidupan kekal bukan diberikan nanti kedatangan tetapi pada saat seseorang mengaku percaya sebagai Tuhan dan Juruselamat.

Ada banyak ayat Alkitab yang menjadi dasar keyakinan orang percaya, misalnya Yohanes 11:25-26, Yohanes 14:6, Roma 10:9, 1 Yohanes 5:11-13. Ayat-ayat ini menjadi dasar keyakinan iman orang yang percaya Yesus. Bagian lain dalam 1 Tesalonika 4:14, bahwa, " semua orang yang percaya kepada Yesus akan dikumpulkan bersama-sama dengan Yesus ketika Yesus datang yang kedua kali.

Jadi Allah sebagai pemilik Sorga, yang telah merencanakan keselematan di dalam Yesus dan bagi mereka yang percaya pasti memiliki hidup yang kekal.

\section{Gambaran umum tentang misi}

\section{a. Arti Misi}

Misi dari bahasa Latin "missio" dalam bahasa Yunani ialah "apostello". Istilah ini tidak hanya dipahami dalam arti umum bahwa mengirim, tetapi lebih dipahami mengirim secara otoritas. Penekanan dalam misi Allah adalah Allah sebagai sumber, inisiator, dinamisator, pelaksana dan penggenap misi-Nya.

Ada istilah lain yaitu "prosthetics" berasal dari kata "prostithenal" (Kisah Para Rasul 2:41, 47; 11:24). Istilah ini kemudian dikembangkan oleh Abraham Kuyper bahwa Tuhan menambahkan bilangan orang-orang yang diselamatkan ke dalam gereja. 
Henk Venema menjelakan misi berdasarkan Yohanes 20:21 dalam tiga perbedaan besar, antara lain: a. missio Dei. Artinya pengutusan oleh Allah. Allah sendiri bertindak sebagi subjek segala pengutusan, terutama pengutusan anak-Nya; b. Missio Filii. Artinya pengutusan oleh Anak. Yesus Kristus diutus oleh Allan dan Yesus Kristus mengutus juga para rasul dan gereja-Nya; c. Missio Ecclesiae, artinya pengutusan oleh gereja.

Jadi misi artinya cara Allah yang berdaulat dalam menyelamatkan dengan mengirim orang-orang percaya supaya melalui kegiatan misi orang lain menjadi percaya.

\section{b. Dasar Alkitab tentang Misi Allah 1) Menurut Perjanjian Lama}

Israel adalah umat pilihan Tuhan, yang hidup dalam ruang perjanjian Tuhan dan berkat yang dijanjikan-Nya dan dituntut untuk hidup kudus, sedangkan bangsabangsa yang di luar perjanjian itu diserahkan Tuhan kepada kecemaran diri mereka (Rm. 1:18-32).

Jika kita menyelidiki Perjanjian Lama, maka ada hari depan bagi semua bangsa di dunia.

Dalam Perjanjian Lama (PL) dan Perjanjian Baru (PB), Tuhan menyatakan rencana keselamatan. Bukan hanya kepada orang Israel tetapi seluruh umat manusia. (bndk. Wahyu 5:9-10; Kej. 1:26-28).

\section{2) Menurut Perjanjian Baru}

Seluruh Perjanjian Baru boleh disebut "buku misi" karena dengan satu tujuan "supaya kamu percaya, bahwa Yesus-lah Mesias, Anak Allah dan supaya kamu oleh imanmu memperoleh hidup dalam nama-Nya (Yoh. 20:31).

Dalam Injil-injil, Yesus Kristus menepati janji Perjanjian Lama (Luk. 2:11). Konsep ini berbeda dengan konsep orang Yahudi bahwa Yesus akan datang sebaga Raja yang membebaskan manusia dari pemeritahan Romawi, namun cara kedatangannya berbeda karena Ia datang sebagai hamba yang menderita (Yes. 53). Sikap Yesus Kristus terhadap Israel dan bangsa-bangsa (Yoh. 3:16 = universal), rahasia Yesus Kristus dibuka (Ef. 3:3-6; Rm. 16:25-27). Jadi rahasinyanya dinyatakan pada waktu Yesus mati dan bangkit (Mat. 24:14). Yesus Kristus mengeluarkan perintah misi dalam Mat. 10:5-8 Mat. 28:18-20 Mark. 16:15-16 Luk. 24:46-48 Yoh. 20:21 Kis. 1:8.

Dalam Kisah Para Rasul, kegerakan Roh Kudus mulai nyata sebagai penggenapan akan pernyataan Tuhan Yesus bahwa Ia akan mencurahkan Roh Kudus setelah Ia naik ke Surga. Roh Kudus sebagai alat misi guna menginsafkan manusia akan dosa agar kembali kepada kebenaran. Hasil misi yang sangat luar biasa karena orang banyak yang percaya dan menyerahkan diri untuk dibaptis sebagai tanda pertobatan.

Surat-surat Paulus dengan tegas memberikan pemahaman bahwa semua yang percaya wajib melaksanakan misi. Kesadaran akan misi sebagai panggilan Kristus menjadi hal yang penting dalam hidup. Paulus sendiri memberikan contoh dalam melakukan misi, mulai dari misi pertama sampai ketiga dengan menjalani daerahdaerah yang sesuai dengan petunjuk dari Tuhan dan sekaligus melibatkan orang lain terlibat dalam misi, misalnya Filemon, Titus, dan lain-lain. 
Pengumpulan orang-orang dalam Kerajaan Sorga menjadi tujuan yang paling tertinggi. Pada saat kedatangan Yesus yang kedua, semua orang yang percaya dikumpulkan bersama-sama di Sorga dan akan terjadi pesta perjamuan Anak Domba, Kristus akan memerintah dalam kekekalan dan Ia sendiri akan menjadi penerang sampai selama-lamannya, amin. Hal ini sangat menggembirakan hati kita yang telah percaya, bahwa kita akan diubahkan dalam kemuliaan yang tak akan binasa sebab kita yang percaya akan dikenakan tubuh kemuliaan yang tidak dapat binasa.

\section{c. Motivasi Misi}

Motivasi adalah penyebab yang menghasilkan suatu tindakan, sedangkan tujuan adalah hasil yang diharapkan dapat tercapai melalui tindakan itu.

Motivasi orang Kristen melakukan misi adalah karena kasih karunia Allah telah dicurahkan kepada kita, Kristus telah mati bagi kita dan telah menebus kita supaya kita menjadi milik-Nya, maka terdorong oleh kasih-Nya, itulah kita mau kembali kepd-Nya.

Jika seseorg memiliki motivasi yang murni, maka ia pasti memiliki jiwa yg lurus, baik antara Allah dan manusia; sebaliknya jika seseorang tidak memiliki motivasi yang murni, betapapun banyak bakat, ia tidak akan mencapai hasil yang positif dan menyeluruh.

Kesucian dan kemurniaan adalah hal yg sangat penting pada saat kita melayani. Seseorang yang memiliki motivasi yg murni maka

- $\quad$ Tidak mudah mengalami depresi pada saat putus asa

- $\quad$ Tidak mudah kompromi pada saat menghadapi musuh yang kuat

- $\quad$ tidak mudah goyah pada saat menghadapi banyak godaan

Motivasi yg benar memiliki:

- $\quad$ kekuatan yang besar pada saat paling melelahkan

- $\quad$ Memberi keteguhan pada waktu penganiayaan

- $\quad$ Memberi sukacita pada waktu sengsara menekan

Apakah sebenarnya motivasi yang murni dalam melakukan misi? Menurut Stephen Tong, ada beberapa motivasi misi, antara lain:

1. Kehendak Allah

a. Kehedendak Allah berarti segala sesuatu yang ditetapkan di dalam Allah

b. Pimpinan Roh Kudus akan membawa manusia masuk kehendak Allah. Pada saat seseorang percaya, maka Roh Kudus dimareraikan dalam hatinya (Ef. 1:13) yang memimpinnya dalam hal-hal yang benar.

c. Misi adalah hal yang sudah Allah tetapkan dalam kekekalan dan dipercayakan kepada kita untuk melaksanakannya maka kita tidak dipengaruhi oleh hasil kita

2. Pengutusan Kristus

a. Kita memberitakan Injil karena Raja di atas segala raja dan Tuhan di atas segala tuan telah mempercayakan tugas tersebut kepada kita.

b. Dalam 1 Kor. 9:17, bahwa kita memiliki perasaan hutang karena kita sudah diselamatkan. 
c. Tuhan yang begitu terhormat dan mulia, menyerahkan tugas itu kepada kita, sehingga kita pun memiliki rasa tanggungjawab yang serius terhadapnya

3. Dorongan Kasih Kristus

a. Roma 5:8 = Allah menunjukkan kasih-Nya kepada kita ketika kita masih berdosa

b. $\quad 2$ Kor. 5:15 = Kristus telah mati untuk kita, supaya mereka yang hidup tidak lagi hidup untuk dirinya sendiri tetapi untuk Dia, yang telah mati dan telah dibangkitkan.

c. Jika seseorg mengalami kasih Allah dan menyelami kasih Allah maka dengan sendirinya ia dapat mengasihi Tuhan dengan lebih baik.

d. 2 Kor. 5:14, mengatakan bahwa kasih Kristus yang menguasai.

4. Perasaan Berhutang

a. Kita yg percaya memiliki utang terhadap dunia, yaitu utang Injil (Rm. $1: 14)$

b. Apakah kita memiliki perasaan berhutang terhadap dunia?

5. Pengharapan Maranatha

a. Injil Kerajaan akan diberitakan di seluruh dunia, barulah tiba kesudahan (Mat. 24:14)

b. Apa yg dilakukan dalam menanti kedatangan-Nya:

1. Menyucikan diri

2. Menyelesaikan pekerjaan-Nya melalui misi

\section{d. Tujuan Misi Allah}

Allah sebagai pencipta manusia dan segala isi dunia, dan tujuan Allah menciptakan manusia adalah untuk memuliakan Allah. Tujuan tertinggi manusia adalah segenap hidupnya mempermuliakan Allah.

Manusia sebagai ciptaan Allah telah menyalahgunakan free will dengan tidak bertanggungjawab sehingga akibatnya manusia mengalami kejatuhan dalam dosa.

Manusia yang telah jatuh dalam dosa, membutuhkan pemulihan relasi dengan Allah sebagai Pencipta dan tujuan misi Allah yaitu menyelamatkan manusia dari dosa agar kembali kepada Allah.

Tujuan misi Allah ke dalam dunia bagi manusia berdosa sebagai nyata kasih Allah bagi manusia. Manusia hanya bisa pulih karena Allah yang mencari dan menyelamatkan manusia.

\section{e. Cara Allah menyatakan misi}

Semua manusia telah berdosa dan kehilangan kemuliaan Allah (Rm. 6:23). Allah menyatakan misi-Nya melalui menggenapkan janji-Nya dalam pribadi Yesus.

Tidak ada cara lain dalam mencapai kehendak-Nya yang sempurna selain di dalam Yesus Kristus, sebab Kristuslah yang direncakan oleh Allah untuk menggenapkan karya keselamatan bagi manusia, bahwa Krituslah yang harus mati di kayu salib untuk menyelamatkan manusia dari dosa.

Allah bermisi sebagai cara yang terpenting guna mencari dan menyelamatkan manusia yang berdosa. 


\section{KEDAULATAN ALLAH DALAM MISI}

Pada bagian ini, penulis menjelaskan beberapa hal yang berkaitan dengan kedaulatan Allah dalam misi, antara lain Allah yang merencanakan keselamatan, Allah yang bersabda melalui para nabi, Allah yang berinkarnasi, karya Roh Kudus dalam mewujudkan misi Allah dan misi Allah melalui gereja.

a. Allah yang merencanakan keselamatan

Pada awal penciptaan, manusia sebagai makhluk yang sempurna karena diciptakan menurut gambar dan rupa Allah. Manusia sebagai makhluk yang diberi hak penuh untuk mengatur segala sesuatu yang berhubungan dengan alam semesta.

Kejatuhan manusia dalam dosa dan perencanaan karya keselamatan di dalam Yesus Kristus merupakan penetapan Allah di dalam kekekalan. Artinya Allah sebagai pribadi yang berdaulat melihat lebih jauh dan telah merencanakan keselamatan di dalam diri Yesus Kristus.

Allah dalam kedaulatan-Nya menunjukkan diri-Nya secara jelas dalam karya keselamatan di dalam Yesus Kristus. Perencanaan keselamatan sebagai bukti bahwa Allah berdaulat atas segala sesuatu terutama memberikan perencanaan keselamatan di dalam Yesus.

b. Allah yang bersabda melalui para nabi

Setelah Allah merencanakan keselamatan, Allah menyatakan secara nyata melalui para nabi dengan nubuatan-nubuatan yang sangat jelas dalam Alkitab. Nubuatan dalam Alkitab tersebut antara lain:

\section{- Amos \\ - Yesaya 53 \\ - $\quad$ Mikha 5}

Semua bagian Alkitab ini memberikan keyakinan kepada kita bahwa Allah yang berdaulat dalam mengkonfirmasikan kehendak-Nya dalam menyelamatkan manusia sangat jelas melalui para nabi. Para nabi berbicara atas nama Allah dalam kedaulatan Allah yang memakai dan menginspirasikan kehendak-Nya bagi manusia. Hal ini terjadi sebagai penggenapan karya keselamatan di dalam Yesus Kristus, sebab Allah dalam mencapai manusia, sasaran-Nya adalah manusia.

\section{c. Allah yang berinkarnasi}

Orang percaya mengimani bahwa Allah sebagai pribadi yang transenden tetapi juga yang imanen. Sebagai Allah yang transenden, manusia tidak bisa mengerti kehendak-Nya secara tuntas. Secara imanen, Allah menyatakan diri-Nya melalui pribadi Yesus.

Dalam Filipi 2:6-8, berbunyi:

“yang walaupun dalam rupa Allah, tidak menganggap kesetaraan dengan Allah itu sebagai milik yang harus dipertahankan, melainkan telah mengosongkan diri-Nya sendiri, dan mengambil rupa seorang hamba, dan menjadi sama dengan manusia. Dan dalam keadaan sebagai manusia, Ia telah merendahkan diri-Nya, dan taat sampai mati, bahkan sampai mati di kayu salib." 


\section{PHRONESIS: JURNAL TEOLOGI DAN MISI \\ VOL. 1 NO. 1 EDISI JANUARI-JUNI 2018. ISSN. 262 1-2684}

Inkarnasi Yesus Kristus, merupakan cara Allah menyingkapkan diri-Nya bagi manusia supaya manusia mengenal Allah dan supaya melalui cara demikian menjadi jembatan antara manusia dan Allah. Allah yang tidak terbatas datang ke dalam dunia yang terbatas supaya dapat dikenal oleh manusia. Hal ini dilakukan Allah karena kasih-Nyan bagi manusia dan dalam wujud manusia, Allah sudah menyingkapkan diri-Nya.

d. Karya Roh Kudus dalam mewujudkan misi Allah

Pribadi ketiga Allah Tri-Tunggal adalah Roh Kudus. Allah Bapa sebagai Pencipta dan perencana keselamatan, Allah Anak sebagai pribadi yang telah menggenapkan rencana keselamatan tersebut datang dengan wujud manusia, yang lahir, mati dan bangkit pada hari yang ketiga sebagai bukti bahwa Yesus bukan hanya manusia tetapi Yesus adalah Allah yang berinkarnasi.

Salah satu karya Roh Kudus sebelum seseorang percaya kepada Yesus adalah menginsafkan manusia akan dosa (Yoh. 16:8) atau menyadarkan manusia agar kembali kepada Allah untuk hidup dalam pertobatan dan memuliakan Allah dengan segenap aspek hidupnya.

Misi Allah terlaksana dalam kaitannya dengan pekerjaan Roh Kudus yang menggugah hati manusia untuk kembali memuliakan Sang Pencipta-Nya. Artinya seseorang menjadi percaya bukan karena cara manusia dalam semua pendekatan misi yang dipakai, misalnya dengan penjelasan Evangelist Explosion (EE) atau penyampaian Firman yang diatur dengan baik, tetapi hanya karena karya Roh Kudus yang memungkinkan seseorang sehingga ia percaya kepada Tuhan Yesus sebagai Tuhan dan Juruselamat dan bertobat dalam meninggalkan kebiasaan hidup yang lama.

e. Misi Allah melalui gereja/orang percaya

Gereja adalah persekutuan orang yang telah beriman kepada Tuhan Yesus sebagai Tuhan dan Juruselamat secara pribadi. Gereja hadir sebagai alat misi dari Allah untuk mencapai apa yang menjadi rencana Allah.

Orang yang sudah percaya dapat mengusahakan iman agar terjadi pertumbuhan iman ke arah seperti Kristus, melalui kegiatan-kegiatan rohani seperti kebaktian, Pendalaman Alkitab (PA), seminar, Kebaktian Kebangunan Rohani (KKR) dan membaca buku-buku rohani. Disamping itu, ia juga berusaha dengan kegiatan kontemplasi yang secara terus-menerus memberikan arah kesadaran untuk semakin mengerti rencana Allah dalam hidupnya.

Setelah terjadi kedewasaan iman, maka diharapkan gereja dapat menjalankan misi Allah dengan melibatkan orang banyak untuk terlibat dalam pekerjaan Allah, karena Allah hanya memakai orang-orang yang telah hidup berkenan dan telah bersedia dipakai oleh Allah dengan segala karunia dan talenta yang diberikan kepadanya.

Gereja diberi mandat yang sangat jelas dalam melakukan misi. Oleh karena itu, bagaimana gereja bersikap atas tugas misi yang telah diberikan oleh Allah. Tugas misi tersebut menjadi suatu keharusan bagi gereja. Gereja salah atau berdosa jika tidak melakukan misi.

Dalam pendekatan misi gereja terhadap dunia, tentunya bersikap arif dan bijaksana sehingga tidak terjadi kecurigaan yang negatif. Hal ini tentunya memerlukan pergumulan yang panjang dan menjadi hal yang serius dipikirkan untuk 
secara efektif dalam pendekatan misi, sehingga pendekatan dan pelaksanaan misi menjadi tepat sasaran dan menjadi berkat bagi orang lain.

Beberapa tanggung jawab gereja terhadap misi antar lain:

1. Pembawa damai (Mat. 5:9).

Orang Kristen adalah orang-orang yang sudah mengaku bahwa Yesus sebagai Tuhan dan Juruselamat secara pribadi dan mampu melakukan berbagai tuntutan Tuhan (iman Kristen=saya beriman karena anugrah Allah dan saya harus hidup sesuai dengan Firman Tuhan).

Mengapa "berbahagia" orang yang membawa damai? Setiap kualitas itu (watak Kristiani) dijunjung tinggi karena yang memperlihatkan kualitas itu disebut "berbahagia". Kata Yunani = makarios yang artinya menganggap dirinya beruntung atau bersenang hati atau bersukacita dan ini merupakan perkenan Allah.

Damai artinya tidak ada kekacauan atau keributan, pertengkaran, seseorang mau berdamai karena hatinya suci dan orang yang mau berdamai karena keterbukaan dan kesungguhan hati.

Sebagai orang percaya kita tidak boleh mencari gara-gara atau menjadi biang keladi suatu konflik.

Kita harus berdamai karena kita yang tadinya berseteru dengan Allah tetapi sekarang didamaikan dengan Allah dan hal ini terjadi karena Anugrah Allah. Kristus mati karena mendamaikan kita dengan Allah. Kita orang percaya sudah didamaikan oleh Allah melalui Kristus (Kol. 1:20).

Dunia di mana ada gereja, penuh dengan berbagai pertentangan dan permasalahan sehingga kehadiran gereja kiranya menjadi pembawa damai. Dengan kata lain orang percaya/gereja yang sudah didamaikan melalui Yesus Kristus perlu memberikan warna yang berbeda dalam masyarakat.

Gereja menjadi alat pendamai dalam hidup bermasyarakat supaya orang lain yang belum percaya melihat dan mereka juga secara tidak sadar sedang diarahkan pada cara yang benar.

Gereja sebagai alat pendamai bagi dunia karena gereja sebagai lambang yang menunjukkan kehadiran kerajaan Allah.

Apakah orang Kristen sudah dianggap pembawa damai dalam keluarga, gereja, masyarakat dan Negara?Tidak ada dendam, tidak ada batasan karena Kristus, justru kenyataan dalam gereja terjadi pengkotak-kotakan, misalnya yang kaya hanya berteman dengan yang kaya, pendeta/majelis hanya kunjungan pada jemaat yang kaya. Tembok pemisah semakin tebal karena gereja membiarkan dosa berkembang, Alkitab disalahtafsirkan, pandangan umum menjadi ukuran bukan lagi Alkitab.

Sering terjadi pertengkaran di dalam gereja dan gereja menjadi rusak karena masalah internal, misalnya uang, kedudukan, perzinahan, dll.

2. Menjadi garam dan terang.

Garam berfungsi sebagai pengawet, sebagai pemberi rasa. Terang berfungsi menerangi kegelapan. Di mana ada terang maka kegelapan akan hilang dan terang yang menguasai.

Kehadiran gereja kiranya seperti perkataan Tuhan Yesus bahwa kamulah garam dunia dan terang dunia (Mat. 5:13-16). Gereja sebagai garam yang harus memberi rasa, tetapi jika tidak, maka mengatakan bahwa garam tersebut dibuang dan diinjak orang. Status kita yang percaya juga disebut terang. Terang menerangi kegelapan karena terang tersebut diletakan di kaki diann yang berfungsi menerangi semua 


\section{PHRONESIS: JURNAL TEOLOGI DAN MISI \\ VOL. 1 NO. 1 EDISI JANUARI-JUNI 2018. ISSN. 262 1-2684}

orang. Yesus mengharapkan setiap orang percaya menjadi terang supaya melaluinya orang banyak menjadi percaya.

Gereja selalu menjadi sorotan orang banyak sehingga kehadiran gereja perlu bersikap menjadi garam dan terang. Artinya kehadiran gereja bersikap baik terhadap semua orang.

Kehadiran gereja dapat mempengaruhi orang lain dalam berbagai bidang kehidupan sehingga ada dampak positif yang terjadi bagi orang lain.

3. Memberikan pandangan hidup berdasarkan Alkitab

Manusia adalah makhluk yang dicipta dengan seperangkat budaya atau berbagai aturan dalam bermasyarakat atau berbudaya. Budaya sebagai kreasi manusia. Manusia yang telah jatuh dalam dosa mengakibatkan budaya menjadi kotor juga. Dengan demikian perlu ada penyaringan yang benar berdasarkan Alkitab.

Alkitab adalah Firman Allah yang menjadi standar tertinggi dan fondasi iman Kristen. Alkitab sebagai ukuran dalam menilai semua tingkah laku manusia dalam bertindak.

Cara yang tepat dalam mempengaruhi atau bermisi bagi orang yang belum percaya adalah cara hidup orang percaya yang didasarkan pada pola Alkitab. Alkitab menjadi patokan dalam bersikap sehingga tidak terpengaruh dalam melakukan misi.

4. Memberikan dorongan untuk memperhatikan pendidikan

Mencerdaskan manusia adalah bagian dari mandat budaya. Pendidikan membentuk prilaku manusia yang akhirnya memberikan pengaruh dalam hidup bersama. Orang Kristen diberikan talenta untuk mengembangkan cara pendidikan yang tepat.

Gereja adalah alat perpanjangan tangan Tuhan dalam melaksanakan misi di dunia, sehingga kehadiran gereja bukan hanya membicarakan hal-hal yang bersifat rohani atau hanya membicarakan Alkitab, tetapi kehadiran gereja bersifat holistik. Gereja juga bertanggungjawab memperhatikan pendidikan sebagai cara memajukkan kerajaan Allah bagi manusia.

5. Terlibat dalam aksi sosial

Kehadiran gereja bukan bersifat inklusif tetapi dapat mendemonstrasikan dirinya di tengah-tengah dunia sebagai cara dalam menjalankan kehedak Allah bagi dunia.

Gereja adalah perkumpulan orang-orang yang sudah percaya. Kehadiran gereja bukan hanya dalam misi atau pelayanan kepada orang percaya, tetapi juga melibatkan diri dalam aksi sosial karena kehadiran gereja bersifat eksklusif, dengan kata lain gereja sebagai alat dalam menjalankan kehendak Allah melalui aksi sosial.

John Howard Yoder berkata,

"Gereja tidak hanya sekedar membawa berita rekonsiliasi, seperti koran atau perusahan telepon yang dapat menyampaikan berita yang bisa dipercaya. Dan juga gerja bukan hasil dari sebuah pesan, sama seperti kumpulan alumni adalah hasil dari sekolah atau kumpulan orang-orang dalam teater adalah hasil dari reputasi film tersebut. Orang-orang yang berkumpul tersebut adalah orangorang yang dipanggil untuk suatu kumpulan sosial yang utuh dan ini merupakan kerja Tuhan, yang memberi makna terhadap sejarah." 


\section{PHRONESIS: JURNAL TEOLOGI DAN MISI \\ VOL. 1 NO. 1 EDISI JANUARI-JUNI 2018. ISSN. 262 1-2684}

Dapat disimpulkan bahwa, pelayanan sosial adalah respon atas kebaikan Allah yang dialami oleh gereja atau orang percaya.

6. Memiliki kasih

Alkitab menyatakan bahwa walaupun seseorang memiliki segala sesuatu tetapi jika tidak memiliki kasih, maka iman yang dimilikinya adalah sia-sia (1 Kor. 13).

Kita disebut sebagai gereja (satu tubuh di dalam Kristus). Menurur Peter Wagner bahwa salah satu ciri gereja yang bertumbuh adalah sesama anggota jemaat saling mengasihi dan saling memperhatikan. Rick Warren, mengatakan bahwa orang percaya yang dewasa adalah yang tidak mementingkan diri sendiri (bndk. Mat. 20:28; 1 Yoh. 3:16; Yoh. 13:34-35).

Martin Luther berkata, "orang Kristen adalah seorang tuan yang merdeka, tidak tunduk kepada siapa pun: orang Kristen adalah seorang pelayan yang penuh pengabdian bagi semua orang,tunduk kepada semua orang."

Jadi kehadiran gereja adalah mewujudnyatakan kasih bagi dunia sehingga melaluinya gereja memberikan dampak yang bermakna bagi dunia.

\section{KESIMPULAN}

Manusia adalah pribadi yang diciptakan menurut gambar dan rupa Allah (Kej. 1:26-28), dengan tujuannya adalah segenap hidupnya memuliakan Allah, namun manusia sebagai gambar Allah yang telah rusak akibat dosa karena telah menyalahgunakan kebebasan yang diberikan padanya. Allah yang berdaulat telah merancangkan keselamatan di dalam Yesus Kristus, dengan menggenapkan-Nya dengan kehadiran Yesus Kristus.

Alkitab secara jelas menyatakan bahwa Allah berdaulat atas segala sesuatu, baik di langit maupun di bumi sehingga Ia berdaulat mengatur segala sesuatu.

Visi Allah adalah memulihkan hubungan Allah dengan manusia yang sudah rusak akibat dosa dengan cara Allah bermisi. Allah yang berdaulat dalam menyatakan misi dengan merancanakan keselamatan dan menggenapkannya di dalam Yesus Kristus serta karya Roh Kudus yang bekerja dalam hati orang berdosa agar kembali kepada Allah, di mana orang percaya sebagai alat Allah dalam menjalankan misi, sehingga orang percaya diharapkan hidup yang menjadi berkat dalam segala bidang kehidupan. 


\section{DAFTAR PUSTAKA}

Berkhof, Louis, Doktrin Allah, Jakarta: LRII, 1993

Brill, Wesley J., Dasar Yang Teguh, Bandung: Kalam Hidup, 1999

Enns, Paul, The Moody Handbook of Theology - Buku Pegangan Teologi, Malang: SAAT, 2008

Ferguson, Sinclair B., Anak-anak Allah yang Hidup, Surabaya: momentum, 2003

Hadiwijono, Harun, Teologi Reformatoris abad ke-20, Jakarta: BPK. Gunung Mulia, 2011

Hoekema, Anthony A., Manusia: Ciptaan Menurut Gambar Allah, (Surabaya: Momentum, 2003)

Kapolyo, Jeo M., The Human Condition, (England: Inter-Varsity Press)

Ludji, Barnabas, Kerajaan Mesias (telaah Kritis Kitab Amos, Yesaya, dan Mikha), Jakarta: Sekolah Tinggi Teologi Jakarta, 1999

McDowell, John dan Bart Larson, Allah menjadi Manusia, Bandung: Lembaga Literatus Baptis, 1976

Piper, John, The Passion of Jesus Christ - lima puluh alasan mengapa Dia datang untuk mati, Surabaya: Momentum, 2010

Susabda, Yakub B., Mengenal dan Bergaul dengan Allah, Batam: Gospel Press, 2002

Tong, Stephen, Mengetahui Kehendak Allah, Surabaya: Momentum, 1999

Tong, Stephen, Kerajaan Allah, Gereja dan Pelayanan, Surabaya: Momentum, 2001

Tong, Stephen, Iman dan Agama, Surabaya: Momentum, 2003

Tong, Stephen, Teologi Penginjilan, Surabaya: Momentum, 2000

Tomatala, Yakob, Teologi Misi, Jakarta: YT Leadership Foundation, 2003

Venema, Henk, Injil Untuk Semua Orang, (Jakarta: YKBK, 1997)

Wongso, Peter, Keselamatan (Doktrin Keselamatan), Malang: SAAT, 1996

Yancey, Philip, Gereja: Mengapa Dirisaukan?, Bandung: Cipta Olah Pusaka, 2001 